\title{
LONGITUDINAL STUDY OF SPORTS INJURIES IN PRACTITIONERS OF AEROBIC GYMNASTICS COMPETITION
}

\author{
ESTUDO LONGITUDINAL DE LESÕES ESPORTIVAS EM PRATICANTES DE GINÁSTICA \\ AERÓBICA DE COMPETIÇÃO
}

Original Article

ARTIGO ORIGINAL

Artículo Original

\author{
ESTUDIO LONGITUDINAL DE LESIONES DEPORTIVAS EN PRACTICANTES DE GIMNASIA \\ AERÓBICA DE COMPETICIÓN
}

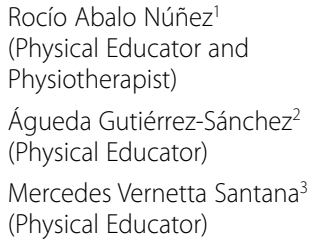

1. University of Vigo, Gies10. Biomedical Research Institute. Faculty of Physiotherapy, Pontevedra, Galicia, Spain. 2. University of Vigo, Gies 10. Biomedical Research Institute. Faculty of Science Education and Sport, Pontevedra, Galicia, Spain. 3. University of Granada, Faculty of Sports Science, Granada, Andalucía, Spain.

\section{Correspondence:}

Faculty of Physiotherapy, Campus A Xunqueira s/n. 36005. Pontevedra. Galicia. Spain. rocioabalo@uvigo.es

\begin{abstract}
Introduction: Aerobic gymnastics, since its membership in the International Gymnastics Federation, has undergone changes in its regulations. Objective: To analyze the injuries found in Spanish aerobic gymnastics athletes during different editions of the Code of Points. Methods: A descriptive, longitudinal and comparative study was carried out on the epidemiology of injuries in aerobic gymnastics published during different editions of the Code of Points. Results: It highlights that the number of injuries decreased from 156 to 38 last year. This decline has been related to the restriction on the number of difficulties in the exercise and the number of elements to be performed on the floor. However, they have increased the number and value of the difficulties. Conclusions: Therefore, it is concluded that the changes made in the regulations are intended to safeguard the health of athletes and ensure that competition develops at its best artistic and technical aspect.
\end{abstract}

Keywords: health, prevention, sports.

\section{RESUMO}

Introdução: A ginástica aeróbica, desde sua adesão à Federação Internacional de Ginástica, passou por mudanças em seus regulamentos. Objetivo: Analisar as lesões encontradas nos atletas espanhóis de ginástica aeróbica durante as diferentes edições do Código de Pontos. Métodos: Realizou-se um estudo descritivo, Iongitudinal e comparativo sobre a epidemiologia de lesões na ginástica aeróbica publicado durante as diferentes edições do Código de Pontos. Resultados: Salienta-se que o número de lesões diminuiu de 156 para 38 no ano passado. Este declínio tem sido relacionado com a limitação do número de dificuldades no exercício e o número de elementos a serem feitos no solo. No entanto, eles aumentaram o número e valor das dificuldades. Conclusões: Portanto, concluiu-se que as modificações feitas nos regulamentos destinam-se a salvaguardar a saúde dos atletas e garantir que a competição se desenvolva no seu melhor aspecto artístico e técnico.

Palavras-chave: saúde, prevenção, esportes.

\section{RESUMEN}

Introducción: La gimnasia aeróbica desde su pertenencia a la Federación Internacional de Gimnasia ha sufrido cambios en su reglamentación. Objetivo: Analizar las lesiones que los deportistas españoles de gimnasia aeróbica presentaron durante las diferentes ediciones del Código de Puntuación. Métodos: Se ha realizado un estudio descriptivo, longitudinal y comparativo sobre la epidemiología de las lesiones en la gimnasia aeróbica publicado durante las diferentes ediciones del Código de Puntuación. Resultados: El estudio destaca la disminución del número de lesiones, de 156 a 38 en el último año. Esta disminución ha tenido relación con la restricción del número de dificultades en el ejercicio y la cantidad de elementos a realizar en el suelo. Sin embargo, han aumentado el número y el valor de las dificultades. Conclusiones: Por tanto, han concluido que las modificaciones que se realizan en la reglamentación tienen como objetivo velar por la salud de los deportistas y garantizar que la competición se desarrolle en su máximo esplendor artístico y técnico.

Palabras clave: salud, prevención, deporte.

\section{INTRODUCTION}

Aerobic Gymnastics (GA) as a competitive mode is incorporated in the year 1994 into the International Gymnastics Federation (FIG), being regulated by the Code of Points (CP), documents published by the technical committee of the institution. From then until now, one of the features of the GA to federal level, has been the ongoing regulatory review to which it is subject, in order to achieve better functional structure and a better harmony and coherence among its judges ${ }^{1}$.
This evolution has generated research nationally and internationally that analyze this sport from different perspectives. Thus, several studies agree that the technical requirements that require its practitioners are anaerobic endurance, relative strength, power and explosiveness and flexibility ${ }^{2,3}$. Furthermore, due to the high level of sport that exists today and the changes the sport itself requires the gymnast is constant difficulties including higher level thus increasing their risk to injury4.

So far, there are four editions of the CP, the first in 1995 (Edition 
1995-1996) spanned only two years of the Olympic cycle. Initially, the code was marked by other existing regulations of various institutions, leaving many subjective aspects ${ }^{5}$.

The second regulation (1997-2000), the GA undergoes rapid change, not only in terms of its rules, but on the content of your exercises. It is in this code, when you start to consider the three most important aspects of the sport, technical quality, artistic quality and difficulty of the concept of revolution. This revolution is marked not only by the appearance of technical elements encoded appraisal values the simplest to the most complex, but essentially by the definition of the technical criteria and meet the minimum requirements to obtain the value of such difficulty'. The CP post from 2001 to 2012 marked an important limitation on the value of difficulty both in relation to the number of items to make, as the landings and ground elements.

\section{METHODS}

The procedure carried out in this research was a descriptive, longitudinal and comparative work injuries GA published in those years in Spain ${ }^{6-8}$. Furthermore, we analyzed the CP (1997-2000), (2001-2004), (2005-2008) and (2009-2012) published by the FIG.This work was carried out with the authorization of the authors of the studies analyzed

For the selection of the research related to GA and injuries have been established as inclusion criteria: Papers published during the term of any of the CP; Sample Spanish athletes; Similar instrument of data collection; Data collection in the Championship of Spain.

In the analyzed special interest has been paid to the variables: number of lesions, location, type and stage of work in which they occur.

In the CP are rated globally highlights the difficulty parameter as the most relevant.

\section{RESULTS}

Based on the inclusion criteria were three works of epidemiology (table 1), but found no work published in the first edition of the CP (19972000). We can observe that the number of injuries is greater in the study of Navarro, Vernetta and Martíne $z^{6}$ and as it descends through the years.

The evolution of the types of injuries can be seen in figure 1, which shows that prevail muscle injuries in the three editions followed by joint and bone injuries falling.

If we analyze the different injury in 2001-04 CP muscle ruptures, in 2005-08 CP equate these and sprains and the CP 2009-12 prevalent strains (figure 2).

On the affected body area shows the high incidence harmful in the lower limbs, but highlights the significant decrease of the upper limb disorders (figure 3).

Studies published in three editions of the CP lesions predominate in the specific technique (figure 4).

Table 1. Lists of Studies found.

\begin{tabular}{|c|c|c|c|c|}
\hline & $\begin{array}{l}\text { Code of } \\
\text { Points }\end{array}$ & Context & Sample & $\begin{array}{c}\text { Number of } \\
\text { injuries }\end{array}$ \\
\hline $\begin{array}{l}\text { Navarro, Vernetta, Martínez } \\
\qquad(2005)^{6} \\
\text { Sports Aerobics: characteristics } \\
\text { of training and injuries in junior } \\
\text { and senior categories }\end{array}$ & 2001-2004 & $\begin{array}{c}\text { V National } \\
\text { Championship }\end{array}$ & 60 & 156 \\
\hline 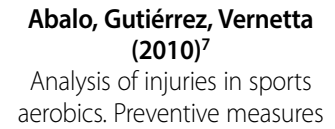 & $2005-2008$ & $\begin{array}{c}\text { XIII Spain } \\
\text { Championship }\end{array}$ & 46 & 29 \\
\hline $\begin{array}{l}\text { Abalo, Gutiérrez, Vernetta } \\
\text { (2012) } \\
\text { Analysis of different training } \\
\text { parameters and incidence of } \\
\text { injury in sports aerobics }\end{array}$ & 2009-2012 & $\begin{array}{c}\text { XVI Spain } \\
\text { Championship }\end{array}$ & 42 & 38 \\
\hline
\end{tabular}

The most notable changes in the four editions of the $\mathrm{CP}$ are shown relative to the difficulty parameter. In the 2009-12 edition there are differences in the number of difficulties that will run the men's singles (IM) and women's singles (IF), about mixed couples (PM), threesomes (TR) and groups (GR) (table 2).

In the last two editions (2005-08 and 2009-12) in the value of the difficulties, the number of elements more difficult and reduce the elements with the lowest score and sometimes disappear.

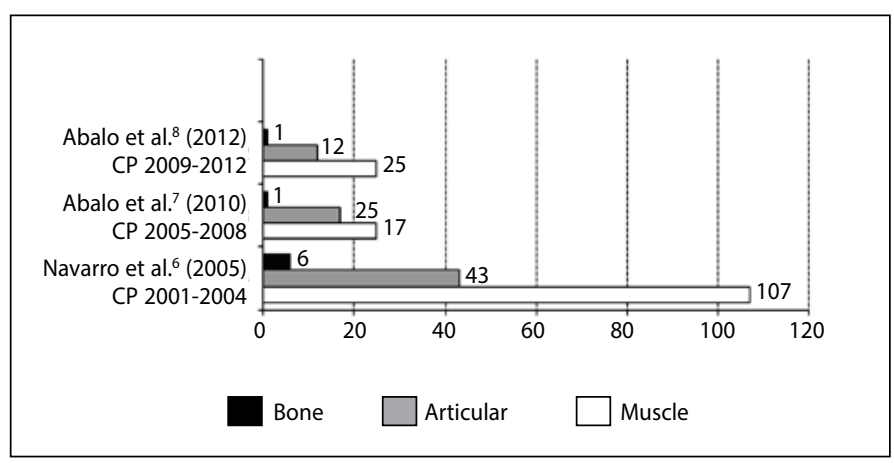

Figure 1. General type of injuries.

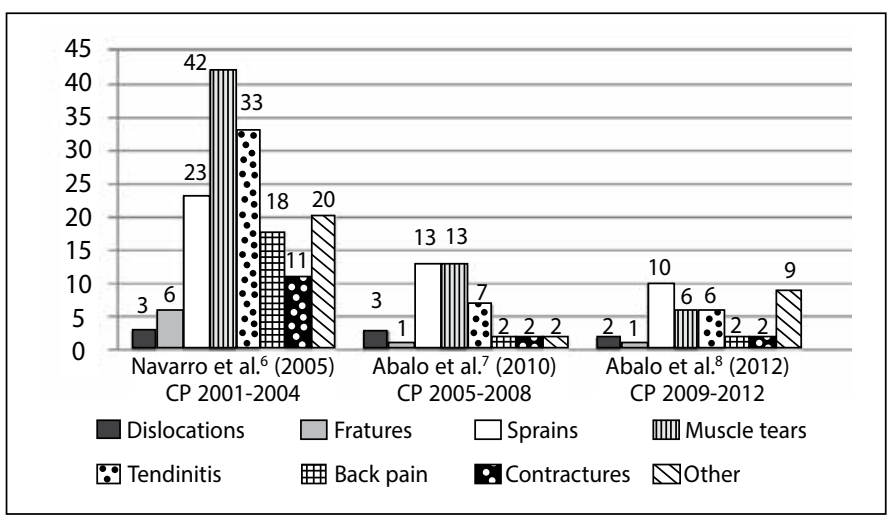

Figure 2. Specific type of injuries.

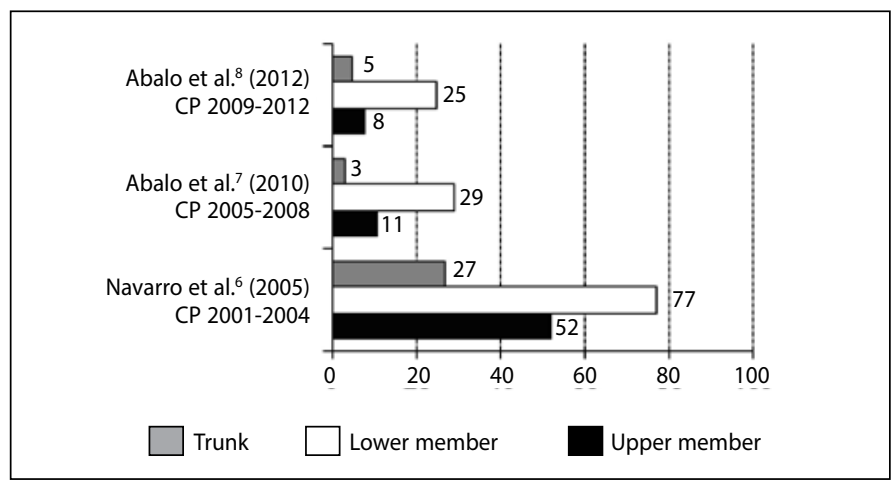

Figure 3. Anatomic location of injuries.

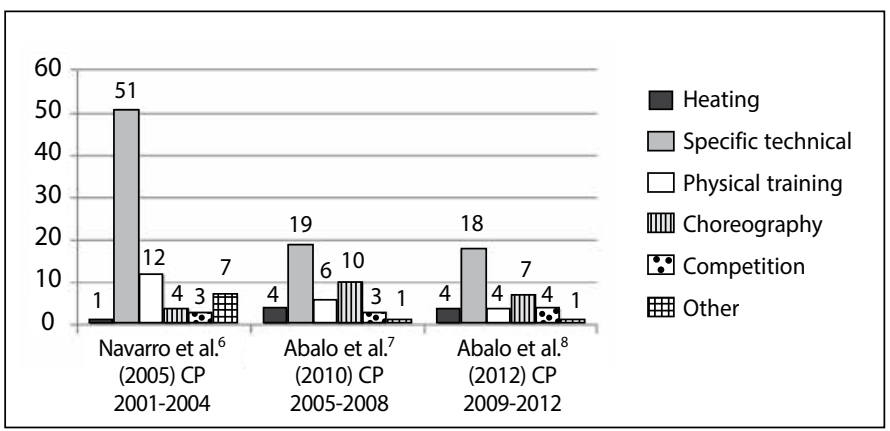

Figure 4. Injuries by the working stage. 
Table 2. Characteristics of different Code Points.

\begin{tabular}{|c|c|c|c|c|}
\hline & $\begin{array}{c}\text { CP } \\
1997-2000\end{array}$ & $\begin{array}{c}C P \\
2001-2004\end{array}$ & $\begin{array}{c}C P \\
2005-2008\end{array}$ & $\begin{array}{c}C P \\
2009-2012\end{array}$ \\
\hline Element groups & 6 & 4 & 4 & 4 \\
\hline $\begin{array}{l}\text { Numbers of difficulies } \\
\text { in routine }\end{array}$ & 16 & 12 & 12 & $\begin{array}{c}10 \mathrm{IM} \text { and IF } \\
12 \mathrm{PM}, \mathrm{TR} \& \mathrm{GG}\end{array}$ \\
\hline $\begin{array}{l}\text { Elements of difficulty } \\
\text { of land }\end{array}$ & $\begin{array}{c}\text { Parts } \\
\text { unlimited }\end{array}$ & Maximum 6 & Maximum 6 & $\begin{array}{l}\text { Maximum } 5 \\
\text { IM and IF } \\
\text { Maximum } 6 \\
\text { PM,TR \& GR }\end{array}$ \\
\hline $\begin{array}{l}\text { Push-up } \\
\text { Landings }\end{array}$ & $\begin{array}{c}\text { Parts } \\
\text { unlimited }\end{array}$ & $\begin{array}{c}\text { Maximum } 2 \\
\text { landings }\end{array}$ & \begin{tabular}{|c|} 
Maximum 2 \\
landings
\end{tabular} & $\begin{array}{c}\text { Maximum } 2 \\
\text { landings }\end{array}$ \\
\hline Landinds to split & $\begin{array}{c}\text { Parts } \\
\text { unlimited }\end{array}$ & $\begin{array}{l}\text { Maximum } 2 \\
\text { landings }\end{array}$ & $\begin{array}{c}\text { Maximum } 2 \\
\text { landings }\end{array}$ & $\begin{array}{l}\text { Maximum } 2 \\
\text { landings }\end{array}$ \\
\hline Level of difficulty & $0.1-0.7$ & $0.1-0.9$ & $0.1-1.0$ & $0.1-1.0$ \\
\hline $\begin{array}{l}\text { Total number of } \\
\text { difficulties }\end{array}$ & 211 & 307 & 345 & 357 \\
\hline
\end{tabular}

\section{DISCUSSION}

Over the years some of the changes undergone by the CP have led to a reduction of injuries, such as the limit on landings push-ups or splits. In the study by Navarro, Vernetta and Martínez ${ }^{6}$ with the CP 2001-04 the incidence of injuries were 2.6 injuries per athlete. With this same regulation in Australia were recorded 2.18 injuries per athlete 9 . Afterwards, Abalo et al. ${ }^{7}$ with the CP 2005-08 are 0.63 injuries per gymnast. These same authors observed the CP 2009-12 0.90 injuries practitioner, indicating a significant reduction of injuries in the last two editions ${ }^{8}$.

Other changes in the rules as the increasing number of elements, the disappearance of items of lesser value and increasing higher value items contribute to increasing demands on the athlete and have more chance of injury by trying to do more complex elements ${ }^{4}$.

All of the works are consistent with other published and have not been studied for not meeting the inclusion criteria9-11 in which the lesions are the most abundant type of muscle. This also happens in rhythmic gymnastics ${ }^{12-14}$.

Unlike dance ${ }^{15-20}$ or gym ${ }^{21,22}$ where most injuries occur in the lower limbs in the GA lesions are present in the upper limbs. This may be due to the overhead of its structures to perform certain exercises because it is an area of the body that is not adapted to withstand heavy loads and body weight ${ }^{23}$. However, a change in the CP 2 limiting the maximum number of elements with push-ups landings has contributed to a decrease of lesions throughout the years.

Another body area affected is the lower limb adductors and hamstrings. Overload problems in these areas is related to the lack of flexibility, strength and repetitive strain, frequency and duration of training ${ }^{24}$, and a poor technique or overtraining ${ }^{25}$.

Injuries occur in different phases of the work of the GA, but in all studies $^{6-9}$ the highest percentage of Lesions are found in the specific technique with different distribution in each of their working sections. This section includes the jumps in the GA group elements are larger and more possibility of difficulty in all editions of different $C P$, hence the frequency of use by gymnasts $1,7,26$.

During the specific technique you learn, develop and mechanized through repetitive techniques, the required elements of difficulty of the exercise and competition. Therefore, the automation of these gestures or elements is what causes high rates of injury in this work phase. In this regard, Torrents ${ }^{4}$ indicates that the specific injury, it may be because the training method used in GA is based on repetition, low variability of their exercises and programs are not individualized.

\section{CONCLUSIONS}

Aerobic Gymnastics is an artistic and technical sport, but where the material value of the Static and Dynamic Strength, Power (jumps) and flexibility, you should always exist because it is one of the main features that give value and excitement to this sport ${ }^{27}$. Thus, the changes that have been made in the various editions of the regulations have been beneficial for athletes because they have led to a decrease in injuries. Thus gymnasts can develop their full physical and artistic skills in a healthier environment.

All authors have declared there is not any potential conflict of interests concerning this article.

\section{REFERENCES}

1. Gutiérrez A, Vernetta M. Análisis y desarrollo evolutivo del parámetro dificultad en la gimnasia aeróbica deportiva. En: González Valeiro MA, Sánchez Molina JA Areces Gayo A (Eds.); IV Congreso de la Asociación Española de Ciencias del Deporte. Universidad de A Coruña: A Coruña; 2006.

2. López J, Vernetta M, De la Cruz, J C. Características morfológicas y funcionales del aeróbic deportivo. Apunts. 1999;55:60-65

3. Torrents $C$, Peralta M, Marina M, Balagué N. Valoración de la fuerza del tren inferior aplicada al salto y de la fuerza del tren superior aplicada a las flexiones en gimnastas e instructores de aeróbic. 4art Congrés de les ciencies de l'esport, l'educació física i la recreació del'INEFC de Lleida Lleida: INEFC; 1999.

4. Torrents C. La teoría de los sistemas dinámicos y el entrenamiento deportivo. [Tesis doctoral]. Universidad de Barcelona, Lleida, España; 2005.

5. Vernetta M. Aeróbic Deportivo: Características, evolución, entidades reguladoras y normativas del Código de Puntuación. II Jornadas Internacionales de Gym-Jazz y Aeróbic. Málaga: Instituto Andaluz del Deporte; 1998.

6. Navarro E, Vernetta M, Martínez I. Aeróbic deportivo: características del entrenamiento y lesiones encontradas en categoría junior y absoluta. Medicina del Deporte. 2005;3:10-16.

7. Abalo R, Gutiérrez A, Vernetta M. (2010). Análisis de las lesiones en deportistas de Gimnasia Aeróbica. Medidas de Prevención. En Romo V, Martínez A (Eds.). Programa de doctorado en Didácticas Especiales. Santiago de Compostela: Andavira. p.383-96.

8. Abalo R, Gutiérrez-Sánchez A, Vernetta, M. Análisis de diferentes parámetros de entrenamiento e incidencia lesional en deportistas de gimnasia aeróbica. Arch Med Deporte. 2012;XXIX(150):740-9.

9. Fetterplace J. The nature and rate of injury in elite sport aerobics athletes. [Coursework Master Thesis]. Victoria University: Australia, 2004.

10. Navarro E, Martínez I,Vernetta M. Influencia del pavimento utilizado y las lesiones en aeróbic deportivo. Lecturas, Educación Física y Deportes [Internet] 2004. [acceso 15 de diciembre de 2012]; Disponible en: http://www.efdeportes.com/efd75/lesion.htm

11. Abalo, R. Prevención de lesiones en deportistas de gimnasia aeróbica mediante ecuaciones de regresión logística. [Tesis Doctoral]. Universidad de Vigo, España; 2011

12. García J. Gimnasia. En: Navés V, Salvador M, Puig i Gros. Traumatología del Deporte. 2a ed. Barcelona: Salvat; 1986. p 65-75.

13. Rozenblat M. Gymnastique et traumatologie. Cinesiologie. 1998;182(37):205-9.

14. Mendizábal S. Fundamentos de la Gimnasia Rítmica. Madrid: Gymnos; 2001.

15. Baillon, JM. Lesions articulaires et musculaires chez les danseurs. Act Orthop Belg. 1983;1-2:112-6.

16. Sammarco GJ. Diagnosis and treatment in Dancers. Clin Res Orthop Relat. 1984;187:176-87.

17. Fernandez-Palazzi F, Rivas S, Pérez Y. Lesiones en bailarines de ballet clásico. Arch Med Deporte 1992;8(35):309-13.

18. Garrick JG, Requa RK. Ballet Injuries. An analysis of epidemiology and financial outcome. Am J Sports Med. 1993;21(4):586-9

19. Milán KR. Injury in Ballet: a review of relevant topics for the physical therapist. J Orthop Sports Phys Ther. 1994;19(2):121-9.

20. Sobrino FJ, Guillén P. Lesiones en el Ballet. Estudio epidemiológico. En: Guillén P. Lesiones Deportivas Madrid: Fundación MAPFRE Medicina; 1996. p 38-43.

21. Lindner KJ, Caine DJ. Injury patterns of female competitive club gymnasts. Can. J Sci Sport 1990;15(4):254-61

22. Kolt GS, Kirkby RJ. Epidemiology of injury in elite and subelite female gymnasts: a comparison of retrospective and prospective findings. Br J Sports Med. 1999;33:312-8.

23. Caine D. Injury and Growth. Scientific Aspects of Women's Gymnastic. Med Sport Sci. Basel, Karge 2003:45:46-71.

24. Grana WA, Weiker GG. Lesiones en Gimnasia Rítmica. En: PAFH Renström. Prácticas Clínicas sobre asistencia y prevención de Lesiones Deportivas. Barcelona: Paidotribo; 1999. p 45-50.

25. Martínez JL, Santoja, F, Pastor A. (1987). Repercusión de la danza sobre el sistema músculo esquelético del tren inferior. Arch Med Deporte. 1987;4(14):155-9.

26. Vernetta M, Gutiérrez A, López Bedoya J, Navarro E. Análisis y Evolución del concepto Dificultad en el Código actual (2001-2004) del Aeróbic Deportivo. VI Simposium de Actividades Gimnásticas. INEFC de Barcelona; 2001

27. Vernetta, M, Gutiérrez A, López Bedoya J, Sánchez, R. La dificultad en el código actual (FIG 2001-2004) del Aeróbic Deportivo. Lecturas, Educación Física y Deportes [Internet] 2003. [acceso 15 diciembre de 2012]; Disponible en: http://www.efdeportes.com/efd64/aerobic.htm 